\begin{tabular}{llllllllllll}
$\mathbf{S}$ & $\mathbf{P}$ & $\mathbf{R}$ & $\mathbf{A}$ & $\mathbf{W}$ & $\mathbf{O}$ & $\mathbf{Z}$ & $\mathbf{D}$ & $\mathbf{A}$ & $\mathbf{N}$ & $\mathbf{I}$ & $\mathbf{A}$ \\
\hline
\end{tabular}

ROCZNIKI TEOLOGICZNE

Tom LXVI, zeszyt 9 - 2019

KS. ADAM PAWLAK

Instytut Historii Kościoła i Patrologii KUL

e-mail: apawlak1989@gmail.com

DOI: http://dx.do.org/10.18290/rt.2019.66.9-12

\title{
SPRAWOZDANIE Z XIV ZJAZDU STOWARZYSZENIA TEOLOGÓW FUNDAMENTALNYCH W POLSCE ,TEOLOGIA FUNDAMENTALNA WOBEC WYZWAŃ WSPÓŁCZESNYCH NAUK O CZŁOWIEKU”
}

W dniach 19-21 września 2018 r. KUL był gospodarzem XIV Zjazdu Stowarzyszenia Teologów Fundamentalnych w Polsce. Wybór miejsca konferencji był podyktowany między innymi obchodzonym w 2018 roku jubileuszem stulecia obecności teologii fundamentalnej na KUL, która była wykładana od początku istnienia uczelni. Wystąpienia były poświęcone praktycznemu tematowi: „Teologia fundamentalna wobec wyzwań współczesnych nauk o człowieku". Zgodnie z tradycją zjazdów co dwa lata podejmuja one zagadnienia praktyczne na przemian z doktrynalnymi. Organizatorem zjazdu były Stowarzyszenie Teologów Fundamentalnych w Polsce oraz Instytut Teologii Fundamentalnej KUL. Patronat naukowy nad wydarzeniem objęły Komitet Nauk Teologicznych PAN, Komisja Teologii Oddziału Lubelskiego PAN i Wydział VI Nauk Teologicznych Lubelskiego Towarzystwa Naukowego.

Celem obrad było zarysowanie odpowiedzi teologii fundamentalnej na współczesne tezy nauk o człowieku. Prelegenci odwoływali się do nauk takich, jak antropologia filozoficzna, medycyna, psychologia, genetyka i konfrontowali z wynikami tych nauk stanowisko teologiczne, szukając adekwatnej odpowiedzi na pytanie: Kim jest człowiek? Ponadto próbowano prognozować, jak w niedalekiej przyszłości człowiek będzie rozumiał samego siebie i jak się zmieni jego relacja do Boga i świata.

Zjazd rozpoczęło zebranie Zarządu Stowarzyszenia Teologów Fundamentalnych w Polsce, które odbyło się 19 września wieczorem. Następnego dnia rano zjazd został zainaugurowany wspólną Mszą świętą, celebrowaną w kościele akademickim, której przewodniczył abp prof. dr hab. Stanisław Budzik, metropolita lubelski. Następnie rozpoczęły się obrady, w które wprowadził ks. dr hab. Jacenty Mastej, prof. KUL, dyrektor Instytutu Teologii Fundamentalnej KUL. Słowo otwarcia wygłosił ks. dr hab. Sławomir Nowosad, prof. KUL, dziekan Wydziału Teologii KUL. Pierwsza z pięciu sesji obrad, zatytułowana: „Cywilizacja chrześcijańska wobec pytania: 
Kim jest człowiek?”, została poprowadzona przez ks. dr. hab. Jacentego Masteja, prof. KUL. Składały się na nią dwa referaty: prof. dr. hab. Andrzeja Zybertowicza (UMK w Toruniu), doradcy społecznego Prezydenta RP, „Oświeceniowa klęska antropologiczna” oraz współautorski „Homo religiosus na skrzyżowaniu medycyny i psychologii”, wygłoszony przez dr. hab. nauk medycznych Jakuba Pawlikowskiego (Uniwersytet Medyczny w Lublinie) i dr. psychologii Marka Jarosza, rektora WSD w Płocku.

Drugą sesję, o temacie „Fundamentalne kwestie współczesnych nauk o człowieku", poprowadził ks. prof. dr hab. Łukasz Kamykowski (UPJPII w Krakowie), członek Zarządu STF. Składały się na nią wystąpienia: ks. dr. hab. Tomasza Kraja (UPJPII w Krakowie) „Kim jest człowiek we współczesnej genetyce? Zagadnienie prawdy o człowieku” oraz ks. dr. hab. Wojciecha Grygiela (UPJPII w Krakowie) „Kim jest człowiek we współczesnych neuronaukach?”. Po tej sesji chętni udali się na zwiedzanie zabytkowych miejsc Lublina.

Wieczorną sesję stanowiły komunikaty naukowe. Tej części przewodniczył ks. prof. dr hab. Tadeusz Dola (UO), przewodniczący Komitetu Nauk Teologicznych PAN.

21 września, przed rozpoczęciem obrad, sprawowano Mszę św., której przewodniczył bp dr hab. Henryk Ciereszko, biskup pomocniczy Archidiecezji Białostockiej. Następnie czwartą sesję obrad poprowadził ks. dr hab. Przemysław Artemiuk, sekretarz STF. Jej tematem było pytanie: „Transhumanizm - nowy etap w dziejach ludzkości?”, a składały się na nią dwa referaty: dr Moniki Białkowskiej, redaktor „Przewodnika Katolickiego”, „Człowieku, jak to się stało? Człowiek i Bóg w drodze do transhumanizmu” oraz dr. Grzegorza Osińskiego (WSKSiM w Toruniu) „Umysłświadomość-dusza w transhumanizmie".

W czasie ostatniej, piątej sesji obrad „Odpowiedź teologii”, prowadzonej przez ks. prof. dr. hab. Tadeusza Dzidka (UPJPII w Krakowie), wiceprzewodniczącego STF, wygłoszono referaty: ks. prof. dr hab. Ireneusz Mroczkowski (UKSW w Warszawie) „Natura osoby ludzkiej a moralna odpowiedzialność chrześcijanina” oraz ks. dr hab. Krzysztof Kaucha, prof. KUL, „Homo Deus? Kim będzie post-człowiek? Kim jest człowiek? Odpowiedź teologii fundamentalnej”. Zjazd został oficjalnie zamknięty przez ks. prof. dr. hab. Henryka Seweryniaka (UKSW), przewodniczącego STF. Następny, XV Zjazd STF odbędzie się we Włocławku.

Podsumowując wygłoszone referaty i podjęte dyskusje, można stwierdzić, że efektem obrad było zarówno rozbudzenie obaw, jak i dodanie nadziei. Współczesne nauki o człowieku odkrywają genialne cechy i możliwości ludzkiego ciała i umysłu, ale czasem starają się zaprzeczyć potrzebie życia duchowego i relacji z Bogiem. Przyszłość dla ludzi wiary wiąże się z wieloma wyzwaniami, czasem z gruntowną zmianą myślenia o sobie samych i otaczającym świecie. Wiara będzie musiała na nowo znaleźć swoje uzasadnienie i miejsce w przekształcających się społeczeństwach. Chrześcijaństwo w tych czasach może stawić czoła nieprzychylnym nurtom współczesnej myśli, jak i wykorzystać zaawansowane wyniki badań dzisiejszych nauk, aby utwierdzać swoją wiarygodność. 